Article

\title{
Briareolate Esters from the Gorgonian Briareum asbestinum
}

\author{
Rian J. Meginley ${ }^{1}$, Prasoon Gupta ${ }^{1}$, Thomas C. Schulz ${ }^{2}$, Amanda B. McLean ${ }^{3}$, \\ Allan J. Robins ${ }^{2}$ and Lyndon M. West ${ }^{1, *}$ \\ 1 Department of Chemistry and Biochemistry, Florida Atlantic University, Boca Raton, FL 33431, \\ USA; E-Mails: rmeginle@fau.edu (R.J.M.); pgupta2@fau.edu (P.G.) \\ 2 Viacyte Inc., 111 Riverbend Rd, Athens, GA 30602, USA; \\ E-Mails:TSchulz@viacyte.com (T.C.S.);ARobins@viacyte.com (A.J.R.) \\ 3 Department of Biochemistry and Molecular Biology, The University of Georgia, Athens, \\ GA 30602, USA; E-Mail: abeggs@uga.edu \\ * Author to whom correspondence should be addressed; E-Mail: 1west@fau.edu; \\ Tel.: +1-561-297-0939; Fax: +1-561-297-2759.
}

Received: 5 June 2012; in revised form: 25 July 2012 / Accepted: 30 July 2012 /

Published: 10 August 2012

\begin{abstract}
Two new briarane diterpenoids briareolate esters J (1) and K (2) were isolated from the methanolic extract of the octocoral Briareum asbestinum collected off the coast of Boca Raton, Florida. The structures of briaranes $\mathbf{1}$ and $\mathbf{2}$ were elucidated by interpretation of spectroscopic data. Briareolate ester K (2) showed weak growth inhibition activity against human embryonic stem cells (BG02).
\end{abstract}

Keywords: Briareum asbestinum; octocoral; briarane; briareolate ester; human embryonic stem cell

\section{Introduction}

Gorgonian corals have provided an abundance of novel structures with many of these demonstrating potentially useful biological activities. The gorgonian Briareum asbestinum has shown to be a plentiful source of diterpenoids belonging to the eunicellin, asbestinane, cembrane, and briarane classes and display numerous biological activities (e.g., cytotoxicity, antimicrobial, anti-inflammatory, antiviral, immunomodulatory, antifouling, and ichthotoxicity) [1]. Briarane-type diterpenoids contain a highly oxidized bicyclo[8.4.0] system of which most contain a $\gamma$-lactone ring. The briareolate esters are a 
small group of briarane diterpenoids isolated from Briareum asbestinum that contain a C-19 methyl ester instead of the typical $\gamma$-lactone ring [2-4].

As part of an ongoing study to discover compounds that impact human embryonic stem cell (hESC) growth we have been screening pre-fractionated and semi-purified marine natural product extract libraries generated using a solid phase extraction (SPE) procedure followed by semi-preparative high pressure liquid chromatography (HPLC) using evaporative light scattering detection (ELSD) directed fractionation (Figure 1). The cell growth inhibitory activities of the pre-fractionated extract libraries are then evaluated against human embryonic stem cells (BG02) using a 96-well plate real-time cell electronic sensing (RT-CES) system to identify compounds that impact self-renewal, differentiation or apoptosis. A plot of cell index (impedance) versus time is used to indicate relative proliferation, differentiation, or death in real-time (Figure 2).

Our previous work using this approach on B. asbestinum resulted in the isolation of three new briareolate esters L-N (3-5) [5]. This included the biologically active compound briareolate ester L (3) that was found to possess a 10-membered macrocyclic ring with a $(E, Z)$-dieneone and was shown to contain a "spring loaded" Michael acceptor that is capable of forming a reversible covalent bond to model sulfur-based nucleophiles. In the present study we report the isolation and structural elucidation of two additional new briarane diterpenoids briareolate esters J (1) and K (2), along with three known compounds from the methanolic extract of $B$. asbestinum that was found to exhibit growth inhibition against BG02 cells (Figure 3).

Figure 1. HPLC chromatogram of the pre-fractionated extract of $B$. asbestinum showing the fractions separated using ELSD-directed collection to generate a semi-purified extract library for biological screening.

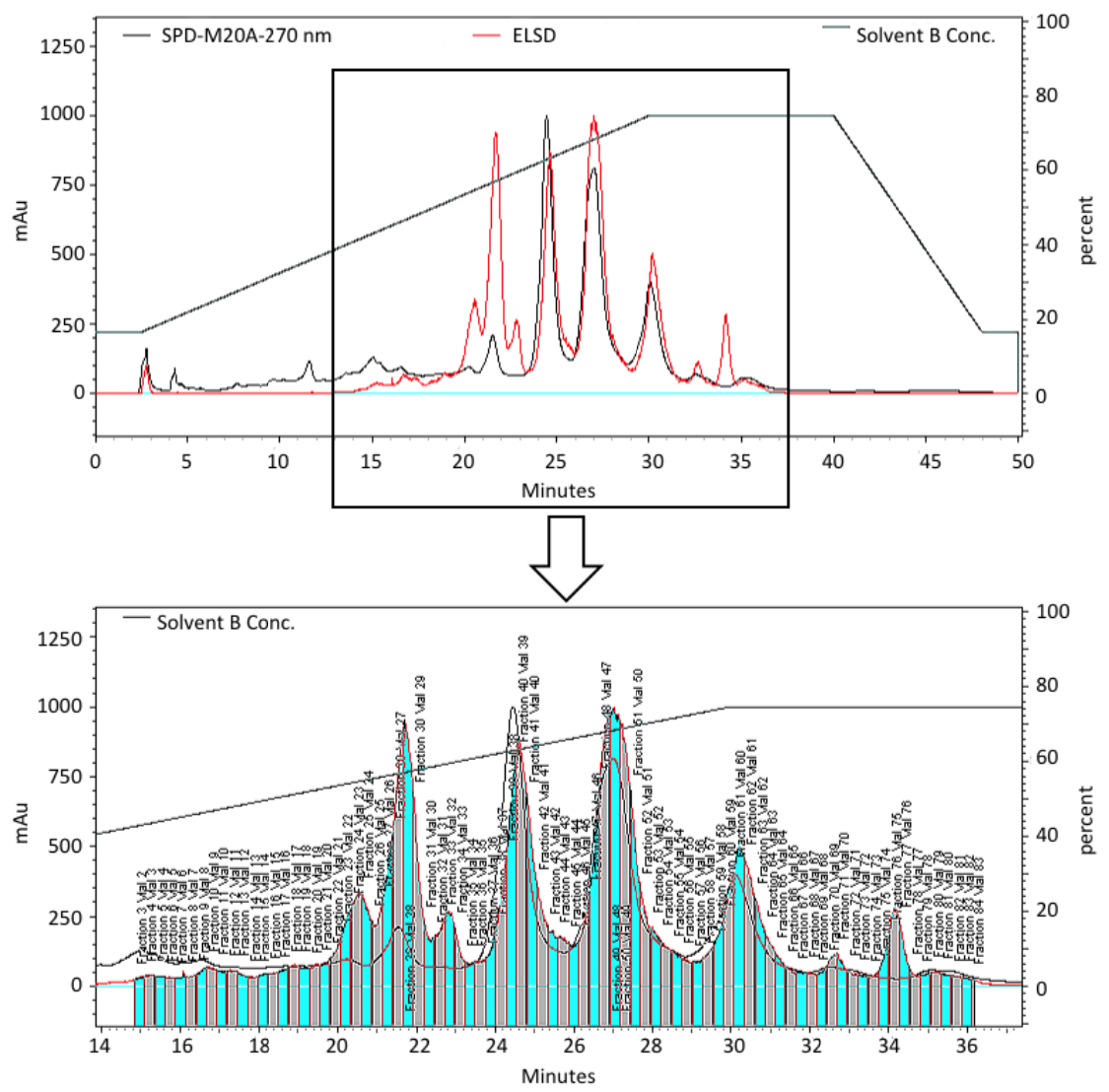


Figure 2. A cell index $v s$. time plot for a pre-fractionated extract library of $B$. asbestinum against the BG02 cell line. A drop in cell index within the first $24-48 \mathrm{~h}$ after addition of the compounds is interpreted as toxicity or induction of apoptosis.

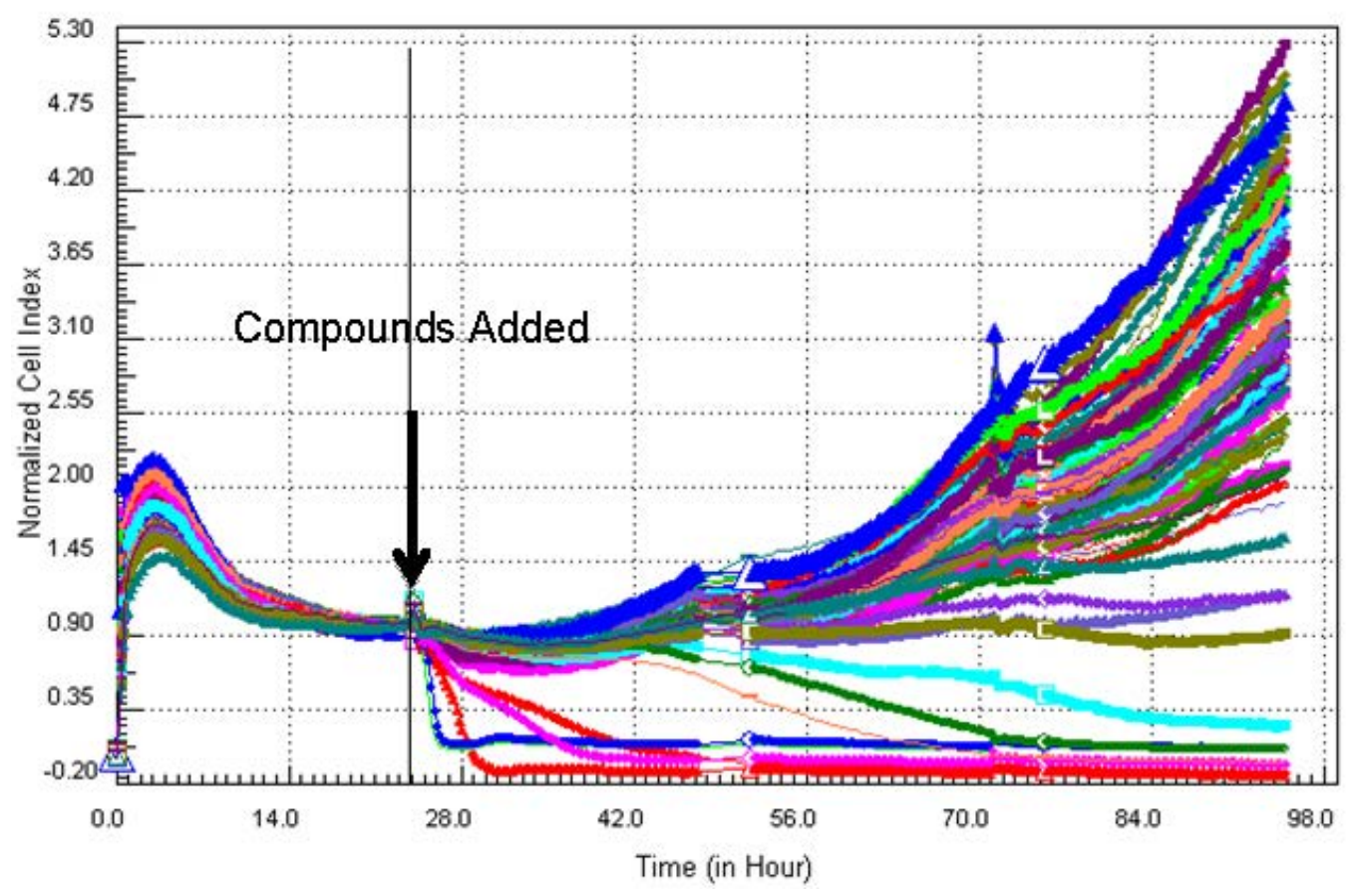

Figure 3. Structures of compounds 1-7.

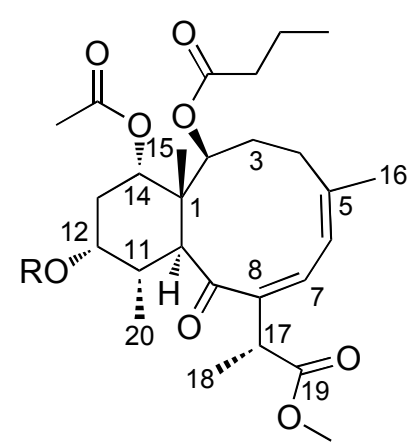

$1 \mathrm{R}=-\mathrm{CO}\left(\mathrm{CH}_{2}\right)_{4} \mathrm{CH}_{3}$

$7 \mathrm{R}=\mathrm{H}$

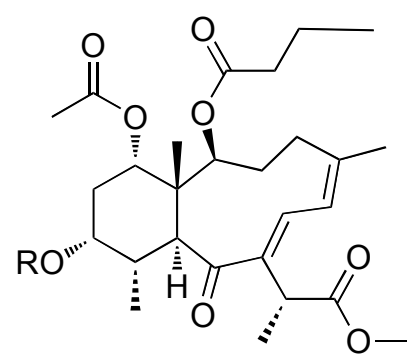

$3 \mathrm{R}=\mathrm{H}$

$4 \mathrm{R}=-\mathrm{CO}\left(\mathrm{CH}_{2}\right)_{4} \mathrm{CH}_{3}$

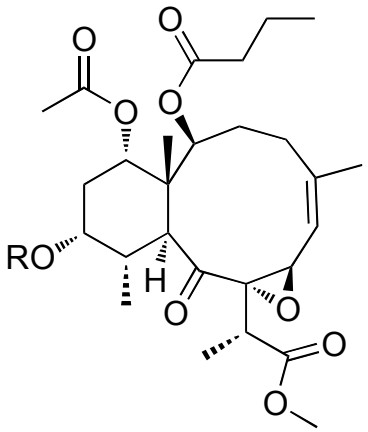

$2 \mathrm{R}=-\mathrm{CO}\left(\mathrm{CH}_{2}\right)_{4} \mathrm{CH}_{3}$

$6 \mathrm{R}=\mathrm{H}$

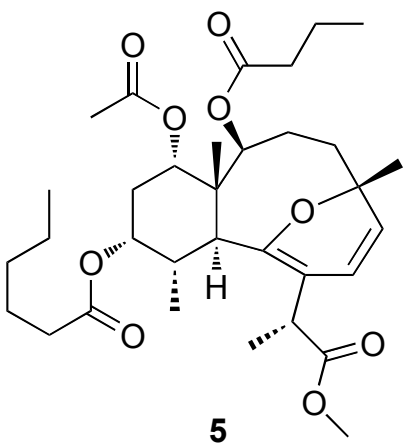




\section{Results and Discussion}

Specimens of Briareum asbestinum (Figure 4) were collected at Hillsboro Ledge, Boca Raton Florida and kept frozen until extraction. The methanolic extract was first fractionated on polymeric HP-20 resin using cyclic loading [6]. The HP-20 column was eluted with $800 \mathrm{~mL}$ fractions of (1) $\mathrm{H}_{2} \mathrm{O}$, (2) $40 \% \mathrm{Me}_{2} \mathrm{CO} / \mathrm{H}_{2} \mathrm{O}$, (3) $75 \% \mathrm{Me}_{2} \mathrm{CO} / \mathrm{H}_{2} \mathrm{O}$ and (4) $\mathrm{Me}_{2} \mathrm{CO}$. The $\mathrm{Me}_{2} \mathrm{CO}$ fraction was then subjected to column chromatography on HP-20SS and normal phase HPLC to yield two new briareolate esters J (1) and $\mathrm{K}(2)$ and three known briareolate esters D (6), G (7), and M (4).

Figure 4. Briareum asbestinum.

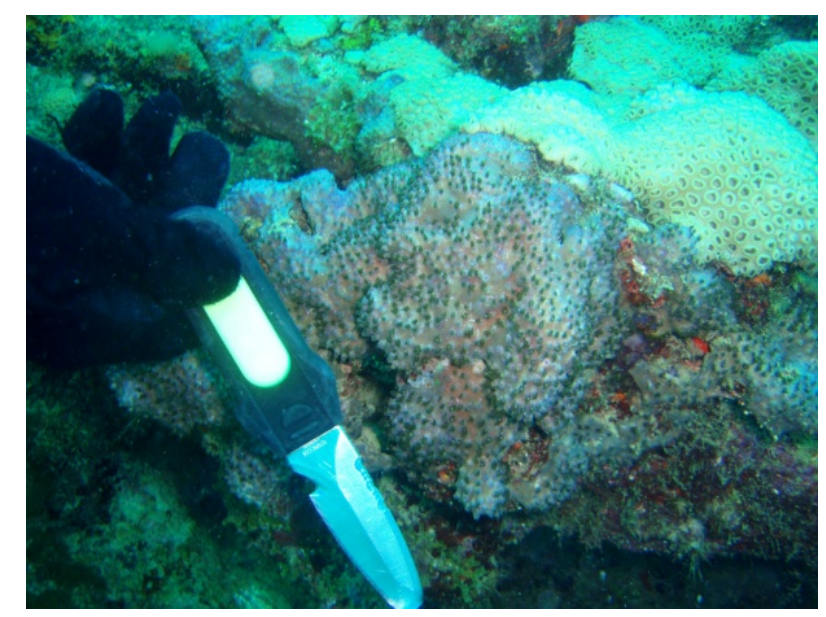

Briareolate ester J (1) was isolated as a colorless oil. The molecular formula of briareolate ester J (1), $\mathrm{C}_{33} \mathrm{H}_{50} \mathrm{O}_{9}$, was determined from the HRESIMS of the $[\mathrm{M}+\mathrm{Na}]^{+}$ion at $\mathrm{m} / z 613.3346,98$ mass units higher than that of briareolate ester $\mathrm{G}(7)$. The presence of a ketone conjugated with two double bonds $\left(\alpha, \beta, \gamma, \delta\right.$-unsaturated ketone) was indicated from a carbonyl carbon with a chemical shift of $\delta_{\mathrm{C}} 207$ (C-9), and the C-C double bond carbons [ $\left.\delta_{\mathrm{C}} 146.3(\mathrm{C}-5), \delta_{\mathrm{C}} 125.3(\mathrm{C}-6), \delta_{\mathrm{C}} 140.9(\mathrm{C}-7), \delta_{\mathrm{C}} 146.3(\mathrm{C}-8)\right]$. The observation of absorption maxima at $\lambda_{\max }=287$ and $225 \mathrm{~nm}$ in the UV spectrum was consistent with this assignment. NOE correlations observed from the olefinic proton $\mathrm{H}-6$ to $\mathrm{H}-7$ and $\mathrm{H}_{3}-16$, together with correlations from $\mathrm{H}-7$ to both $\mathrm{H}-17$ and $\mathrm{H}_{3}-18$, established the $(Z, Z)$-configuration of the dieneone and the $s$-cis conformation of the diene (Figure 5). Additionally, the upfield chemical shift of the olefinic proton $\mathrm{H}-7$ in 1 at $\delta_{\mathrm{H}} 6.74$ compared to $\delta_{\mathrm{H}} 7.64$ in the $(E, Z)$-dieneone briareolate ester L (3), with the $s$-trans diene conformation, confirmed this assignment [5].

A close inspection of the ${ }^{1} \mathrm{H}$ and ${ }^{13} \mathrm{C}$ NMR data (Table 1) revealed the similarity of $\mathbf{1}$ to that of briareolate ester $\mathrm{G}(7)$, except that $\mathrm{H}-12\left[\delta_{\mathrm{H}} 4.89\right.$, br s] was shifted downfield by $1.24 \mathrm{ppm}$ as compared with that of 1 . In addition, in the ${ }^{13} \mathrm{C}$ NMR spectrum the resonance of $\mathrm{C}-12\left(\delta_{\mathrm{C}} 73.7\right)$ was shifted downfield by $2.7 \mathrm{ppm}$ and those of C-11 ( $\left.\delta_{\mathrm{C}} 38.4\right)$ and C-13 $\left(\delta_{\mathrm{C}} 30.2\right)$ were shifted upfield by 0.5 and $1.3 \mathrm{ppm}$, respectively, in comparison with those of $\mathbf{1}$ [4]. This suggested that the 12-hydroxy group of 7, was replaced by a hexanoate group at C-12 in 1, as observed in briareolate esters M (4) and $\mathrm{N}$ (5). The presence of the hexanoate group was confirmed by the NMR data $\left[\delta_{\mathrm{H}} 0.92(3 \mathrm{H}, \mathrm{t}, J=8.0 \mathrm{~Hz})\right.$, ca. 1.31 (4H, overlapped), 1.63 (2H, overlapped), $2.32(2 \mathrm{H}, \mathrm{m}), \delta_{\mathrm{C}} 17.6(\mathrm{q}), 24.0,26.3,33.0$, and 36.1 (each t), $175.1(\mathrm{CO})]$. These assignments were confirmed by COSY, HSQC, and HMBC correlations similar to those observed for $\mathbf{4 , 5}$ and $\mathbf{7}$ (Figure 5). The relative configuration of briareolate ester J (1) 
was determined to be the same as that of $\mathbf{7}$ from the similarity of proton-proton coupling constants and ${ }^{1} \mathrm{H}$ and ${ }^{13} \mathrm{C}$ chemical shifts together with NOE correlations observed in a ROESY experiment (Figure 5).

Table 1. NMR Spectroscopic Data for Briareolate Esters J (1) and K (2) a

\begin{tabular}{|c|c|c|c|c|}
\hline \multirow{2}{*}{ position } & \multicolumn{2}{|c|}{1} & \multicolumn{2}{|r|}{2} \\
\hline & $\delta_{C}$, mult & $\delta_{\mathrm{H}}(J$ in $\mathrm{Hz})$ & $\delta_{\mathrm{C}}$, mult & $\delta_{H}(J$ in $\mathbf{H z})$ \\
\hline 1 & $46.4, \mathrm{C}$ & & $48.8, \mathrm{C}$ & \\
\hline 2 & 73.7, $\mathrm{CH}$ & 5.17, br d (6.0) & $80.5, \mathrm{CH}$ & $5.52, \mathrm{~d}(8.0)$ \\
\hline $3 \alpha$ & $31.3, \mathrm{CH}_{2}$ & $1.89, \mathrm{~m}$ & $31.1, \mathrm{CH}_{2}$ & $2.31, \mathrm{~m}$ \\
\hline $3 \beta$ & & $1.89, \mathrm{~m}$ & & $1.58, \mathrm{~m}$ \\
\hline $4 \alpha$ & $30.2, \mathrm{CH}_{2}$ & $2.20, \mathrm{~m}$ & $34.1, \mathrm{CH}_{2}$ & $2.53, \mathrm{dd}(18.0,8.0)$ \\
\hline $4 \beta$ & & $2.08, \mathrm{~m}$ & & $2.28, \mathrm{~m}$ \\
\hline 5 & $146.3, \mathrm{C}$ & & 147.1, C & \\
\hline 6 & 125.3, $\mathrm{CH}$ & 6.12 , br s & $116.2, \mathrm{CH}$ & 5.47, br d (4.0) \\
\hline 7 & $140.9, \mathrm{CH}$ & 6.74, br s & $64.3, \mathrm{CH}$ & 4.42, br d $(4.0)$ \\
\hline 8 & $146.3, \mathrm{C}$ & & 71.3, C & \\
\hline 9 & 207.0, C & & $211.5, \mathrm{C}$ & \\
\hline 10 & $48.3, \mathrm{CH}$ & $3.79, \mathrm{~d}(12.0)$ & $44.7, \mathrm{CH}$ & $3.06, \mathrm{~d}(12.0)$ \\
\hline 11 & $38.4, \mathrm{CH}$ & $2.19, \mathrm{~m}$ & $36.2, \mathrm{CH}$ & $2.34, \mathrm{~m}$ \\
\hline 12 & $73.7, \mathrm{CH}$ & 4.89, br s & $72.6, \mathrm{CH}$ & 4.98, br s \\
\hline $13 \alpha$ & $30.2, \mathrm{CH}_{2}$ & $2.05, \mathrm{~m}$ & 29.9, $\mathrm{CH}_{2}$ & 2.05, br d $(16.0)$ \\
\hline $13 \beta$ & & $1.86, \mathrm{~m}$ & & $1.99, \mathrm{~m}$ \\
\hline 14 & $75.6, \mathrm{CH}$ & 4.68, br s & 74.6, $\mathrm{CH}$ & 4.69, br s \\
\hline 15 & $14.9, \mathrm{CH}_{3}$ & $1.19, \mathrm{~s}$ & $12.8, \mathrm{CH}_{3}$ & $0.99, \mathrm{~s}$ \\
\hline 16 & $26.3, \mathrm{CH}_{3}$ & $2.19, \mathrm{~s}$ & $26.8, \mathrm{CH}_{3}$ & $1.75, \mathrm{~s}$ \\
\hline 17 & $46.4, \mathrm{CH}$ & $3.45, q(8.0)$ & $40.8, \mathrm{CH}$ & $2.39, \mathrm{q}(8.0)$ \\
\hline 18 & $19.8, \mathrm{CH}_{3}$ & $1.32, \mathrm{~d}(8.0)$ & $13.5, \mathrm{CH}_{3}$ & $1.29, \mathrm{~d}(8.0)$ \\
\hline 19 & 176.7, C & & 175.3, C & \\
\hline 20 & 17.6, $\mathrm{CH}_{3}$ & $0.79, \mathrm{~d}(8.0)$ & $16.8, \mathrm{CH}_{3}$ & $0.75, \mathrm{~d}(8.0)$ \\
\hline $\mathrm{OMe}$ & $52.8, \mathrm{CH}_{3}$ & $3.62, \mathrm{~s}$ & $52.5, \mathrm{CH}_{3}$ & $3.61, \mathrm{~s}$ \\
\hline \multirow[t]{4}{*}{ ester at C-2 } & $175.1, \mathrm{C}$ & & $174.3, \mathrm{C}$ & \\
\hline & $37.7, \mathrm{CH}_{2}$ & $2.19, \mathrm{~m}$ & $37.9, \mathrm{CH}_{2}$ & $2.25, \mathrm{~m}$ \\
\hline & $19.2, \mathrm{CH}_{2}$ & $1.57, \mathrm{~m}$ & 19.7, $\mathrm{CH}_{2}$ & $1.60, \mathrm{~m}$ \\
\hline & $14.5, \mathrm{CH}_{3}$ & $0.92, \mathrm{t}(8.0)$ & $14.5, \mathrm{CH}_{3}$ & $0.93, \mathrm{t}(8.0)$ \\
\hline \multirow[t]{6}{*}{ ester at $\mathrm{C}-12$} & $175.1, \mathrm{C}$ & & $175.4, \mathrm{C}$ & \\
\hline & $36.1, \mathrm{CH}_{2}$ & $2.32, \mathrm{~m}$ & $35.9 \mathrm{CH}_{2}$ & $2.37, \mathrm{~m}$ \\
\hline & 26.3, $\mathrm{CH}_{2}$ & $1.63, \mathrm{~m}$ & $26.4 \mathrm{CH}_{2}$ & $1.64, \mathrm{~m}$ \\
\hline & $33.0, \mathrm{CH}_{2}$ & $1.31, \mathrm{~m}$ & $33.0 \mathrm{CH}_{2}$ & $1.33, \mathrm{~m}$ \\
\hline & 24.0, $\mathrm{CH}_{2}$ & $1.31, \mathrm{~m}$ & $24.0 \mathrm{CH}_{2}$ & $1.33, \mathrm{~m}$ \\
\hline & 17.6, $\mathrm{CH}_{3}$ & $0.92, \mathrm{t}(8.0)$ & $14.8 \mathrm{CH}_{3}$ & $0.95, \mathrm{t}(8.0)$ \\
\hline \multirow[t]{2}{*}{ ester at C-14 } & 172.1, C & & $172.6, \mathrm{C}$ & \\
\hline & $22.1, \mathrm{CH}_{3}$ & $1.98, \mathrm{~s}$ & $22.3 \mathrm{CH}_{3}$ & $1.99, \mathrm{~s}$ \\
\hline
\end{tabular}

${ }^{\mathrm{a}} \mathrm{In} \mathrm{CD}_{3} \mathrm{OD}, 400 \mathrm{MHz}$ for ${ }^{1} \mathrm{H}$ and $100 \mathrm{MHz}$ for ${ }^{13} \mathrm{C}$ NMR. 
Figure 5. Selected 2D NMR correlations for briareolate ester J (1).
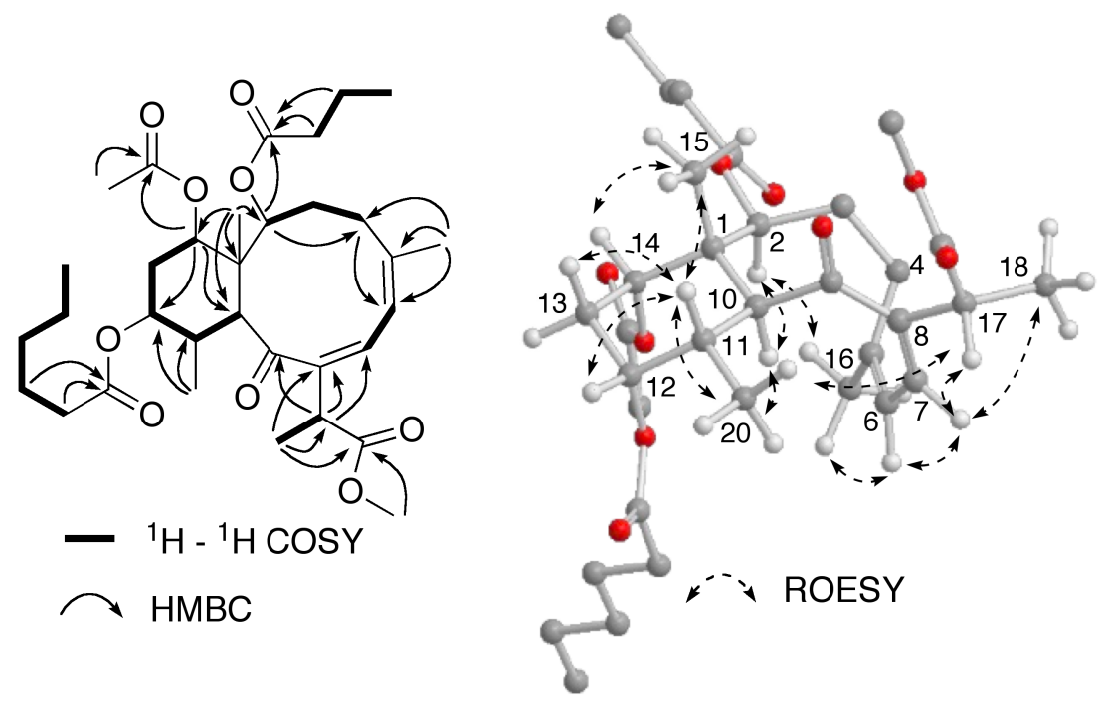

Briareolate ester K (2) was isolated as a colorless oil. The molecular formula of briareolate ester K (2), $\mathrm{C}_{33} \mathrm{H}_{50} \mathrm{O}_{10}$, was determined from the HRESIMS of the $[\mathrm{M}+\mathrm{Na}]^{+}$ion at $\mathrm{m} / \mathrm{z} 629.3291$, one more oxygen atom than that of briareolate ester $\mathrm{J}$ (1). A comparison of the ${ }^{1} \mathrm{H}$ and ${ }^{13} \mathrm{C}$ NMR data (Table 1) revealed that 2 was similar to 1, except that the NMR signals for the C-7-C-8 double bond were missing in the NMR spectra of 2, and instead, resonances for an epoxide were observed in the ${ }^{1} \mathrm{H}$ NMR $\left(\delta 4.42\right.$, H-6) and ${ }^{13} \mathrm{C}$ NMR $\left[\delta_{\mathrm{C}} 64.3\right.$ (s); 71.3 (d)] spectra indicating oxidation of the C-7-C-8 double bond to be an epoxide. HMBC correlations from the oxygenated methine signal at $\delta 4.42(\mathrm{H}-7)$ to $\mathrm{C}-5(\delta 147.1)$ and C-6 ( $\delta$ 116.2) of the trisubstituted double bond, and to C-8 $(\delta 71.3)$ and C-9 $(\delta 211.5)$ are consistent with this assignment. Additional HMBC correlations observed from H-17 to C-7, C-8 and C-9 confirmed this assignment (Figure 6).

Figure 6. Selected NMR correlations for briareolate ester K (2).
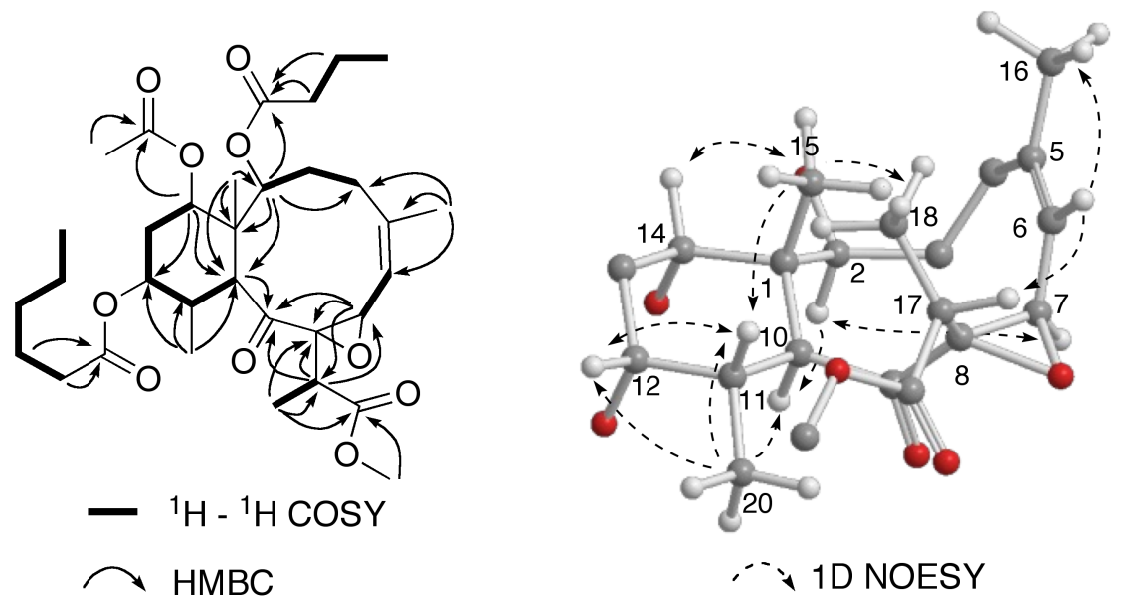

The relative configuration of briareolate ester K (2) was determined to be identical to that of 1 on the basis of NOE enhancements revealed in a series of 1D NOESY experiments (Figure 6). The configuration of the C-7/8 epoxide was determined from NOE enhancements observed between H-7 and $\mathrm{H}-2$ together with NOE enhancements observed from $\mathrm{H}-6$ to $\mathrm{H}-17$ which placed $\mathrm{H}-7$ on the inside 
of the 10-membered ring and indicated the trans orientation of the epoxide. This assignment is consistent with that of briareolate ester D (6) whose structure was assigned on the basis of X-ray crystallography [4].

Compounds 1 and $\mathbf{2}$ were evaluated for cell growth inhibitory activities against human embryonic stem cells (BG02) using a 96-well plate real-time cell electronic sensing (RT-CES) system [7]. Briareolate ester K (2) showed weak growth inhibition against BG02 cells with an $\mathrm{EC}_{50}$ value of $40 \mu \mathrm{M}$. No inhibitory activity was detected for briareolate ester J (1) at $40 \mu \mathrm{M}$. Previously the (E,Z)-dienone containing briareolate esters L (3) and M (4) were found to have growth inhibition against both the BG02 and a pancreatic cancer cell line (BxPC-3) cells with $\mathrm{EC}_{50}$ values of 2.4 and $9.3 \mu \mathrm{M}$, respectively for $\mathbf{3}$, and $8.0 \mu \mathrm{M}$ against BG02 cells and only cytostatic effects at 13.0 and $17.0 \mu \mathrm{M}$ against the BxPC-3 cells for 4 [5]. No growth inhibition was found for the briareolate esters B, C, G (7), and $\mathrm{N}(\mathbf{5})$. The absence of significant growth inhibition activity for the (Z,Z)-dieneone compound $\mathbf{1}$ and the epoxide containing compound $\mathbf{2}$ further confirms the importance of the $(E, Z)$-dieneone for biological activity.

\section{Experimental Section}

\subsection{General Experimental Procedures}

Optical rotations were measured on a Jasco P-2000 polarimeter $(c: \mathrm{g} / 100 \mathrm{~mL})$ at $589 \mathrm{~nm}$. UV spectra were obtained on a Perkin-Elmer Lambda EZ 210 UV-vis spectrophotometer. IR spectra were recorded on a Thermo Electronic Corporation Nicolet IR-100 spectrophotometer. All NMR spectra were recorded on a Varian MercuryPlus 400 spectrometer. All chemical shifts $(\delta)$ were referenced internally to the residual solvent peak $\left(\mathrm{CD}_{3} \mathrm{OD}:{ }^{1} \mathrm{H}, \delta 3.30 ;{ }^{13} \mathrm{C}, \delta 49.0 ; \mathrm{CDCl}_{3}:{ }^{1} \mathrm{H} 7.26\right.$ ppm; ${ }^{13} \mathrm{C} 77.0$ ppm). Short- and long-range ${ }^{1} \mathrm{H}-{ }^{13} \mathrm{C}$ correlations were determined with gradient-enhanced inverse-detected HSQC and HMBC experiments respectively. NOE correlations were detected with NOESY or ROESY experiments with a $0.5 \mathrm{~s}$ mixing time. The high-resolution ESI mass spectra were obtained using an Agilent 6210 LC-TOF mass spectrometer at the Mass Spectrometer Facility at the University of Florida, Gainesville, Florida. HPLC purifications were performed on Beckman System Gold HPLC system with a 168 UV detector and a SEDEX 85 (Sedere) evaporative light scattering detector. Thin layer chromatography (TLC) analyses were performed using Merck Kieselgel (Aufoilen) $60 \mathrm{~F}_{254}$ plates. TLC plates were visualized by spraying with 1:1 $\mathrm{MeOH}: \mathrm{H}_{2} \mathrm{SO}_{4}$.

\subsection{Animal Material}

The gorgonian Briareum asbesinum was collected by hand using SCUBA at a depth of 45-50 $\mathrm{ft}$ from Hillsboro Ledge, Boca Raton Florida. The specimen was immediately frozen and kept at $-20{ }^{\circ} \mathrm{C}$ until extraction. A voucher specimen has been deposited in the Department of Chemistry and Biochemistry, Florida Atlantic University, Boca Raton Florida (FAU02-010).

\subsection{Extraction and Isolation}

The sample of Briareum asbestinum (500 g wet wt.), were extracted with $\mathrm{MeOH}(3 \times 800 \mathrm{~mL})$ for $24 \mathrm{~h}$. The third, second and then the first extracts were passed through a column of HP-20 resin 
$(2.5 \times 25 \mathrm{~cm})$ equilibrated with $\mathrm{MeOH}$. The combined eluents was diluted with $\mathrm{H}_{2} \mathrm{O}(2.5 \mathrm{~L})$ and passed again through the column. The column was eluted with $800 \mathrm{~mL}$ fractions of: (1) $\mathrm{H}_{2} \mathrm{O}$, (2) $40 \%$ $\mathrm{Me}_{2} \mathrm{CO} / \mathrm{H}_{2} \mathrm{O}$, (3) $75 \% \mathrm{Me}_{2} \mathrm{CO} / \mathrm{H}_{2} \mathrm{O}$ and (4) $\mathrm{Me}_{2} \mathrm{CO}$. Fraction 4 was concentrated to dryness and was subjected to column chromatography on HP-20SS resin eluting with increasing concentrations of $\mathrm{MeCN}$ in $\mathrm{H}_{2} \mathrm{O}(40 \%-100 \%)$. A late eluting fraction was further subjected to semi-preparative silica gel HPLC (Luna $5 \mu \mathrm{m} ; 10 \times 250 \mathrm{~mm} ; 4 \mathrm{~mL} / \mathrm{min} ; 5 \%-50 \%$ EtOAc/Hexane over $30 \mathrm{~min}$ ) to give 1 (6.0 mg), 2 (10.0 mg), 4 (10.0 mg), 6 (10.0 mg) and 7 (5.0 mg).

Briareolate ester J (1): Colorless oil; $[\alpha]^{25}-19$ (c 0.05, MeOH); UV (MeOH) $\lambda_{\max } 225 \mathrm{~nm}(\varepsilon 2711)$, 287 ( $\varepsilon$ 1713); IR (MeOH) $v_{\max } 2956,2867,1737,1641,1454,1371 \mathrm{~cm}^{-1} ;{ }^{1} \mathrm{H}$ and ${ }^{13} \mathrm{C}$ NMR data, see Table 1; HRESIMS $m / z 613.3346[\mathrm{M}+\mathrm{Na}]^{+}$(calcd. for $\mathrm{C}_{33} \mathrm{H}_{50} \mathrm{O}_{9} \mathrm{Na}, 613.3353$ ).

Briareolate ester K (2): Colorless oil; $[\alpha]^{25}-8$ (c 0.05, MeOH); IR (MeOH) $v_{\max } 2951,2869,1742$, 1454, $1367 \mathrm{~cm}^{-1} ;{ }^{1} \mathrm{H}$ and ${ }^{13} \mathrm{C}$ NMR data, see Table 1; HRESIMS $m / z 629.3291[\mathrm{M}+\mathrm{Na}]^{+}$(calcd. for $\left.\mathrm{C}_{33} \mathrm{H}_{50} \mathrm{O}_{10} \mathrm{Na}, 629.3302\right)$.

\subsection{Cell Culture}

BG02 hESCs were grown in defined medium, containing $10 \mathrm{ng} / \mathrm{mL}$ HRG1 $\beta$ (Peprotech), $10 \mathrm{ng} / \mathrm{mL}$ ActA (R\&D Systems), 200 ng/mL LR ${ }^{3}$-IGF1 (JRH Biosciences), and 8 ng/mL FGF2 (Sigma or R\&D Systems). Cultures were passaged with Accutase (Innovative Cell Technologies) and plated on tissue culture flasks coated with growth factor-reduced matrigel (BD Biosciences) diluted 1:200, as described by Robins and Schulz [8].

\subsection{RT-CES Cytotoxicity Assays}

The xCELLigence real-time impedance system (Roche) was used to monitor the effects of compounds on cells [7]. BG02 cells were plated at $1 \times 10^{4}$ cells/well in matrigel coated plates. The culture was placed in the reader station under standard humidified conditions and incubated at $37{ }^{\circ} \mathrm{C}$ with $5 \% \mathrm{CO}_{2}$. The media was changed every $24 \mathrm{~h}$ and impedance was measured every 15 min for 3 days. Compounds were added to quadruplicate wells $24 \mathrm{~h}$ after plating. Vincristine was used as a positive control for cytotoxicity, and DMSO alone was used as a negative control. Cell index plots were normalized immediately prior to addition of compound, and $\mathrm{EC}_{50}$ values were generated using the xCELLigence analysis software RTCA ver 1.1 after 2 days of treatment.

\section{Conclusions}

Two new briarane diterpenoids briareolate esters $J$ (1) and $\mathrm{K}$ (2), along with three known compounds were isolated from the methanolic extract of $B$. asbestinum collected off the coast of Boca Raton, Florida. The compounds were identified from screening semi-purified and pre-fractioned extract libraries against hESCs and briareolate ester K (2) containing a trans C-7/8 epoxide was found to exhibit weak growth inhibition activity against human embryonic stem cells (BG02). The lack of biological activity for briaranes $\mathbf{1}$ and $\mathbf{2}$ further confirmed the requirement of the $\alpha, \beta, \gamma, \delta$-unsaturated ketone in conjunction with the double bond configuration for biological activity. 


\section{Acknowledgments}

This research was supported by the National Institutes of Health Grants P41GM079597 and P01GM085354. We thank T. Vansach (FAU) and R. Barrett (FAU) for assistance in collection of Briareum asbestinum.

\section{References}

1. Berrue, F.; Kerr, R.G. Diterpenes from gorgonian corals. Nat. Prod. Rep. 2009, 26, 681-710.

2. Maharaj, D.; Mootoo, B.S.; Lough, A.J.; McLean, S.; Reynolds, W.F.; Tinto, W.F. Methyl briareolate, the first briarein diterpene containing a C-19 methyl ester. Tetrahedron Lett. 1992, 33, 7761-7764.

3. Dookran, R.; Maharaj, D.; Mootoo, B.S.; Ramsewak, R.; McLean, S.; Reynolds, W.F.; Tinto, W.F. Briarane and asbestinane diterpenes from Briareum asbestinum. Tetrahedron 1994, 50, 1983-1992.

4. Mootoo, B.S.; Ramsewak, R.; Sharma, R.; Tinto, W.F.; Lough, A.J.; McLean, S.; Reynolds, W.F.; Yang, J.P.; Yu, M. Further briareolate esters and briareolides from the Caribbean gorgonian octocoral Briareum asbestinum. Tetrahedron 1996, 52, 9953-9962.

5. Gupta, P.; Sharma, U.; Schulz, T.C.; Sherrer, E.S.; McLean, A.B.; Robins, A.J.; West, L.M. Bioactive diterpenoid containing a reversible "spring-loaded" (E,Z)-dieneone michael acceptor. Org. Lett. 2011, 13, 3920-3923.

6. Houssen, W.E.; Jaspars, M. Methods in Biotechnology. In Natural Products Isolation, 2nd ed.; Sarker, S.D., Latif, Z., Gray, A.I., Eds.; Humana Press: Totowa, NJ, USA, 2006; Volume 20, pp. 353-391.

7. Solly, K.; Wang, X.; Xu, X.; Strulovici, B.; Zheng, W. Application of real-time cell electronic sensing (RT-CES) technology to cell-based assays. Assay Drug Dev. Technol. 2004, 2, 363-372.

8. Robins, A.J.; Schulz, T.C. Media and Extra Cellular Matrix Requirements for Large-Scale ESC Growth. In Emerging Technology Platforms for Stem Cells; Lakshmipathy, U., Chesnut, J.D., Thyagarajan, B., Eds.; Wiley-Blackwell: Oxford, UK, 2009; pp. 251-274.

Samples Availability: Available from the authors.

(C) 2012 by the authors; licensee MDPI, Basel, Switzerland. This article is an open access article distributed under the terms and conditions of the Creative Commons Attribution license (http://creativecommons.org/licenses/by/3.0/). 